Burning the Books 



\title{
Burning the Books
}

A History of the Deliberate Destruction of Knowledge

\author{
RICHARD OVENDEN
}

THE BELKNAP PRESS of HARVARD UNIVERSITY PRESS

CAMBRIDGE, MASSACHUSETTS 
Copyright (C) Richard Ovenden, 2020

All rights reserved.

Printed in the United States of America

First published in Great Britain as Burning the Books: A History of Knowledge Under Attack in 2020 by John Murray (Publishers)

A Hachette UK company

First Harvard University Press edition, 2020

Typeset in Bembo MT Pro by Palimpsest Book Production Ltd, Falkirk, Stirlingshire

Library of Congress Cataloging-in-Publication data is available from the Library of Congress

ISBN 978-0-674-24I20-6 (cloth : alk. paper) 
For Lyn 
